\title{
An Enhanced Opposition-based Firefly Algorithm for Solving Complex Optimization Problems
}

\author{
(Algoritma Kelip Berasaskan Teori Tentangan untuk Penyelesaian Masalah \\ Pengoptimuman Kompleks)
}

Ling Ai Wong*, Hussain Shareef, Azah Mohamed \& Ahmad Asrul Ibrahim

\begin{abstract}
Firefly algorithm is one of the heuristic optimization algorithms which mainly based on the light intensity and the attractiveness of firefly. However, firefly algorithm has the problem of being trapped in local optimum and slow convergence rates due to its random searching process. This study introduces some methods to enhance the performance of original firefly algorithm. The proposed enhanced opposition firefly algorithm (EOFA) utilizes opposition-based learning in population initialization and generation jumping while the idea of inertia weight is incorporated in the updating of firefly's position. Fifteen benchmark test functions have been employed to evaluate the performance of EOFA. Besides, comparison has been made with another existing optimization algorithm namely gravitational search algorithm (GSA). Results show that EOFA has the best performance comparatively in terms of convergence rate and the ability of escaping from local optimum point.
\end{abstract}

Keywords: Enhanced opposition-based firefly algorithm; heuristic optimization

ABSTRAK

Algoritma kelip adalah salah satu algoritma pengoptimuman heuristik berdasarkan keamatan cahaya dan daya tarikan kelip-kelip. Walau bagaimanapun, algoritma kelip mempunyai masalah terperangkap pada optimum setempat dan kadar penumpuan yang perlahan dalam proses capaian rawak. Kajian ini memperkenalkan beberapa kaedah bagi meningkatkan prestasi asal algoritma kelip. Algoritma kelip berasaskan teori tentangan (EOFA) yang dicadangkan adalah berasaskan teori tentangan dan fungsi berat inersia. Lima belas fungsi ukur rujuk telah digunakan bagi menilai prestasi EOFA. Di samping itu, perbandingan juga dilakukan di antara algoritma pengoptimuman sedia ada seperti algoritma pencarian graviti. Keputusan menunjukkan bahawa EOFA mempunyai prestasi yang terbaik dari segi kadar penumpuan dan keupayaan melepaskan diri daripada titik optimum setempat.

Kata kunci: Algoritma kelip berasaskan teori tentangan; pengoptimuman heuristik

\section{INTRODUCTION}

In recent years, heuristic optimization methods have obtained a lot of attention from researchers. This is due to their better performance compared to mathematical optimization methods in coping with large and complex optimization problems. There are different types of heuristic optimization algorithms. One of the early works is Genetic Algorithm (GA) (Goldberg \& Holland 1988), followed by other methods such as Ant Colony Optimization (ACO) (Dorigo et al. 1996), Particle Swarm Optimization (PSO) (Kennedy \& Eberhart 1995), Gravitational Search Algorithm (GSA) (Rashedi et al. 2009) and etc. However, meta-heuristic optimization algorithms have the problem of being trapped in local optimum and slow convergence rates due to their random searching process. This leads to the development of hybrid algorithms that can overcome these issues effectively.

Firefly Algorithm (FA) is an algorithm developed by X. Yang based on the flashing characteristics of fireflies (Yang
2008). The FA is illustrated based on three assumptions where firstly, all fireflies are of the same sex and therefore the attraction between the fireflies is independent. Secondly, the attraction between the fireflies is proportional to their brightness. This means, the brighter ones will attract the less bright ones. The fireflies will move randomly if all fireflies having the same brightness. Thirdly, the brightness of a firefly is decided by the objective function.

Compared to some other heuristic algorithms, FA is relatively more simple and easy to implement. However, like most of the heuristic algorithms, FA is also facing the problem in escaping from local optimum and pre-mature converges. Therefore, some improvements have been done on it by previous researchers. One of the improvements was introduced by $\mathrm{X}$. Yang where a technique known as Levy flight is used to improve the randomization of FA (Yang 2010). Besides, modified FA with cellular learning automata (CLA) was proposed to improve the ability and convergence rate of original FA (Hassanzadeh \& Meybodi 
2012). On the other hand, inertia weight based FA has been implemented to avoid the pre-mature convergence as well as to recover from being trapped in local optimum (Yafei et al. 2012). The improvement made to FA in this research differs from previous works. In order to further improve the performance of original FA in terms of convergence rate, the opposition-based learning (Tizhoosh 2005) is integrated into FA while the idea of inertia weight FA (Yafei et al. 2012) is also incorporated at the same time to improve the ability of FA to escape from local optimum.

\section{CONVENTIONAL FIREFLY ALGORITHM}

Two important components of FA are the light intensity as well as the attractiveness where the attractiveness is decided by the light intensity (brightness) of the fireflies. Since the attraction of a firefly is proportional to the light intensity as discovered by the nearby fireflies, the attractiveness function, $\beta(\mathrm{r})$ can be defined as shown in Equation (1).

$$
\beta(\mathrm{r})=\beta_{\mathrm{o}} e^{-\gamma r m},(\mathrm{~m} \geq 1)
$$

where $\beta$ is the attractiveness for $r=0, \gamma$ is the light absorption coefficient while $r$ is the Cartesian distance between two fireflies as defined in Equation (2).

$$
r_{i j}=\left\|x_{i}-x_{j}\right\|=\sqrt{\sum_{k=1}^{d}\left(x_{i, k}-x_{j, k}\right)^{2}}
$$

where $i$ and $j$ represents two fireflies at $x_{i}$ and $x_{j} . x_{i, k}$ is the kth component of the spatial coordinate $x_{i}$ of $i$-th firefly. At the same time, the movement of the firefly $i$ which is attracted by the brighter one (firefly $j$ ) is defined by Equation (3).

$$
x_{i}=x_{i}+\beta_{o} e^{-\gamma r_{i j}^{2}}\left(x_{j}-x_{i}\right)+\operatorname{alph} a\left(\operatorname{rand}-\frac{1}{2}\right)
$$

where the second term is due to the attraction and the third term is due to the randomization. In the third term, the randomization parameter alpha is used while rand is a random number generator uniformly distributed between zero and one. Meanwhile, alpha is a decreasing function with a decreasing factor, delta as illustrated in Equation (4). The flowchart for FA is shown in Figure 1.

$$
\operatorname{alpha}(t+1)=\operatorname{alpha}(t) \times \text { delta }, \quad 0<\text { delta }<1
$$

The FA have better performance if compared to other algorithms such as PSO and GA in terms of both efficiency and success rate (Yang 2009). However, many researchers noted that the performance of FA becomes less satisfied when the dimension of the search space increased (Rahnamayan et al. 2006; Yang 2009). Opposition based learning could be one of the technique that can improve the performance of FA.

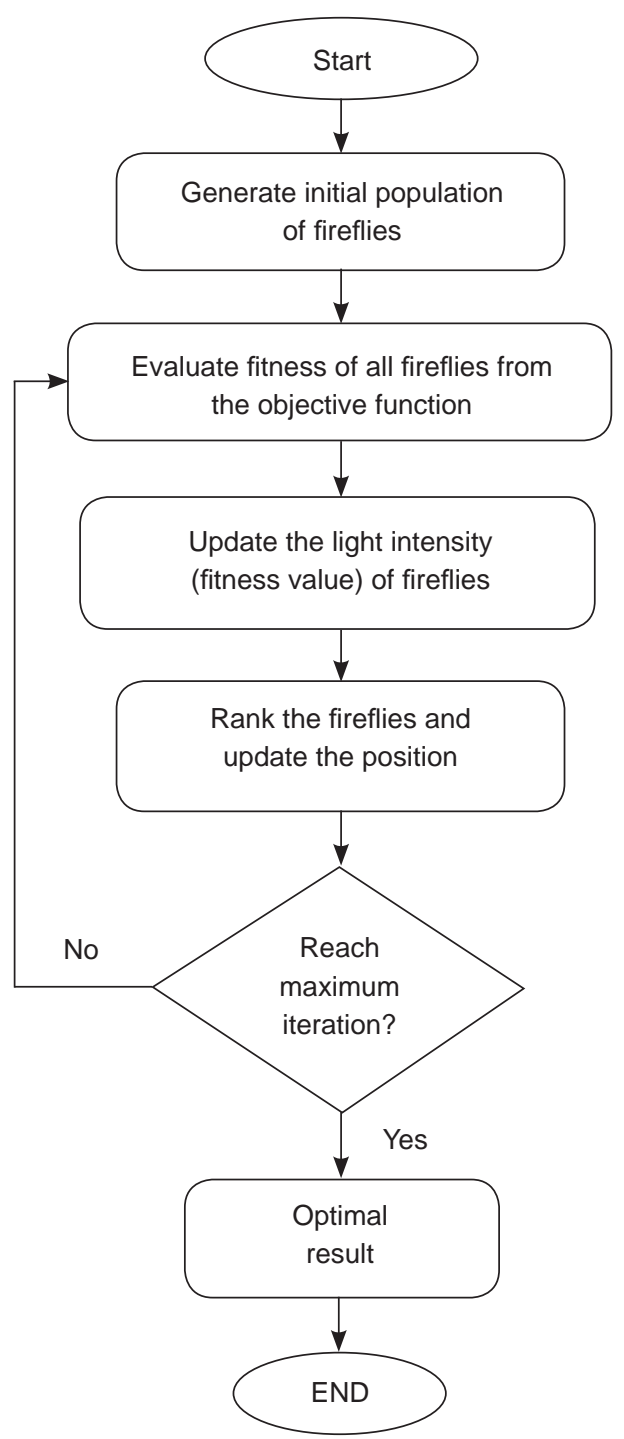

FIGURE 1. Flowchart for Firefly Algorithm (FA)

\section{OPPOSITION-BASED LEARNING}

Opposition-based learning was proposed by Tizhoosh (Tizhoosh 2005) and it has been applied and tested in some heuristic optimization algorithms such as genetic algorithm (Tizhoosh 2005), differential evolution algorithm (Rahnamayan et al. 2006), ant colony optimization (Malisia \& Tizhoosh 2007) and gravitational search algorithm (Shaw et al. 2012) in order to enhance the performance of these algorithms.

Basically, optimization process such as FA always starts with an initial population (solutions) which is created randomly due to the absence of a priori information about the solutions. Then the algorithm will try to search for the best solutions. However, there can be a possibility that the initial guess for the solutions are far away from the actual solutions. The chance to start with the solutions closer to the optimal value can be increased by obtaining the opposite set of solutions simultaneously. Set of population that are closer to the optimal value will be chosen as initial population. The 
similar method can be adopted as well for each solution in the current population. The concept of opposite number is demonstrated below.

Let $x \in R$ be a real number within a defined interval where $x \in[a, b]$. The opposite number $x_{o}$ can be defined as shown in Equation (5).

$$
x_{o}=a+b-x
$$

Similarly, this concept can be extended to the case with higher dimensions. Let $D\left(x_{1}, x_{2} \ldots, x_{\mathrm{m}}\right)$ be a set of points in $\mathrm{m}$ dimensional search space where $x_{i} \in\left[a_{i}, b_{i}\right]$ and $x_{1}, x_{2} \ldots$ $x_{\mathrm{m}} \in R$. Then the points in the opposition set $D_{o}\left(x_{\mathrm{o} 1}, x_{\mathrm{o} 2} \ldots\right.$ $\left.x_{\mathrm{om}}\right)$ can be defined as shown in Equation (6).

$$
x_{o i}=a_{i}+b_{i}-x_{i}, \quad i=1,2, \ldots, \mathrm{m}
$$

By using the definition for opposite number, the opposition based optimization can be developed as follows. Let $D\left(x_{1}, x_{2} \ldots, x_{\mathrm{m}}\right)$ be the set of points in $\mathrm{m}$ dimensions search space which is the candidate solution for an optimization problem. According to opposition theorem, $D_{o}\left(x_{\mathrm{o} 1}, x_{\mathrm{o} 2} \ldots\right.$, $\left.x_{\mathrm{om}}\right)$ will be the opposition set for $D\left(x_{1}, x_{2} \ldots, x_{\mathrm{m}}\right)$. Suppose that $f(x)$ is the function used to measure the performance of candidate solution, thus if $f(D)$ is greater than or equal to $f\left(D_{o}\right)$, then set of points in $D$ can be replaced by $D_{o}$ or else $D$ is maintained.

\section{ENHANCED OPPOSITION-BASED FIREFLY ALGORITHM (EOFA)}

INERTIA WEIGHT BASED FA

In inertia weight based FA (Yafei et al. 2012), an inertia weight function, $\omega(t)$ as shown in Equation (7) was applied to the Equation (3) in the original version of FA described in Section 3.

$$
\omega(t)=\omega_{\max }-\left(\omega_{\max }-\omega_{\min }\right) *(t / \text { Maxgeneration })
$$

where $\omega(t)$ is the inertia weight at $t, \omega_{\max }$ and $\omega_{\min }$ are the initial and final values of the inertia weight respectively through the iteration process, $t$ is the current iteration while Maxgeneration is the maximum number of iterations as defined in the initialization process of FA.

The movement of the firefly in updating its position in inertia weight based FA is shown in Equation (8).

$$
\begin{gathered}
x_{i}(t)=\omega(t) x_{i}(t)+\beta_{o} e^{-\gamma r_{i j}^{2}}\left(x_{j}(t)-x_{i}(t)\right)+ \\
\text { alpha }\left(\operatorname{rand}-\frac{1}{2}\right)
\end{gathered}
$$

The main purpose of the inertia weight based function here is to improve the global exploration at the beginning of optimization process while improve the local exploration at the end of optimization process (Yafei et al. 2012).
EOFA

Opposition-based population initialization and oppositionbased steps for EOFA with the population size of $n$ and dimension of $\mathrm{m}$ are shown in Figure 2. For the initialization, the initial population of fireflies, D is generated randomly, and then the opposite population, $\mathrm{D}_{\mathrm{o}}$ is calculated using Equation (6). The $\mathrm{n}$ fittest fireflies are chosen from $\mathrm{D}$ and $\mathrm{D}_{\mathrm{o}}$ to become the first population in opposition-based optimization process.

In EOFA, each firefly updates the light intensity (fitness value) using Equation (8) after the evaluation of the fitness from the objective function. Then the fireflies will rank and update their positions. In EOFA, a jumping rate, Jr of 1 is used to decide if the opposite population is generated or not according to Equation (9). If Jr is greater than the generated random number, the opposite population will be generated and the next population will be the $\mathrm{n}$ fittest individuals chosen from current $\mathrm{D}$ and $\mathrm{D}_{\mathrm{o}}$ or else, the next population will remain as the current population, D generated from the update of firefly's position. The optimization process repeats until the criteria given is met, where in this case it is the maximum number of iteration.

$$
\begin{gathered}
\text { generation of } \\
\text { opposite population }
\end{gathered}= \begin{cases}y e s, & \text { if } J r>\operatorname{rand}() \\
n o, & \text { otherwise }\end{cases}
$$

The opposition-based optimization enables the algorithm to search for the global optimum points in a faster way. The superior performance of EOFA in escaping from the local optimum points as well as the higher convergence rate is shown in the results.

\section{RESULT AND DISCUSSION}

Fifteen benchmark test functions for unconstrained global optimization (Hedar 2013) have been chosen in order to evaluate the performance of EOFA. The name, dimension size and the global minima of each test function is presented in Table 1. All simulations in this study are done using MATLAB software. Besides, comparison has been done with Gravitational Search Algorithm (GSA) (Rashedi et al. 2009) in order to show the superior performance of EOFA in solving most of the problems. In addition, FA (Yang 2008) is included in the comparison as well to show the improvement of conventional method by using EOFA. In this work, the population size, $\mathrm{n}$ is set to be 50 and the number of maximum iteration is taken as 1000 for all algorithms used in the comparison. For FA and EOFA, the values for $\beta$, initial alpha, delta and gamma are defined as 1, 0.2, 0.97 and 1 respectively. For EOFA, the jumping rate, $\mathrm{Jr}=1$ while the inertia weight, $\omega_{\max }$ and $\omega_{\min }$ are 1.4 and 0.5 respectively. For GSA, the initial gravity constant, $\mathrm{G}_{\mathrm{o}}$ is set to be 100 while the best applying force, Kbest decreases monotonically from $100 \%$ to $2.5 \%$. The parameter $\tau$ is set to be $8 \%$ of the total number of dimensions. 


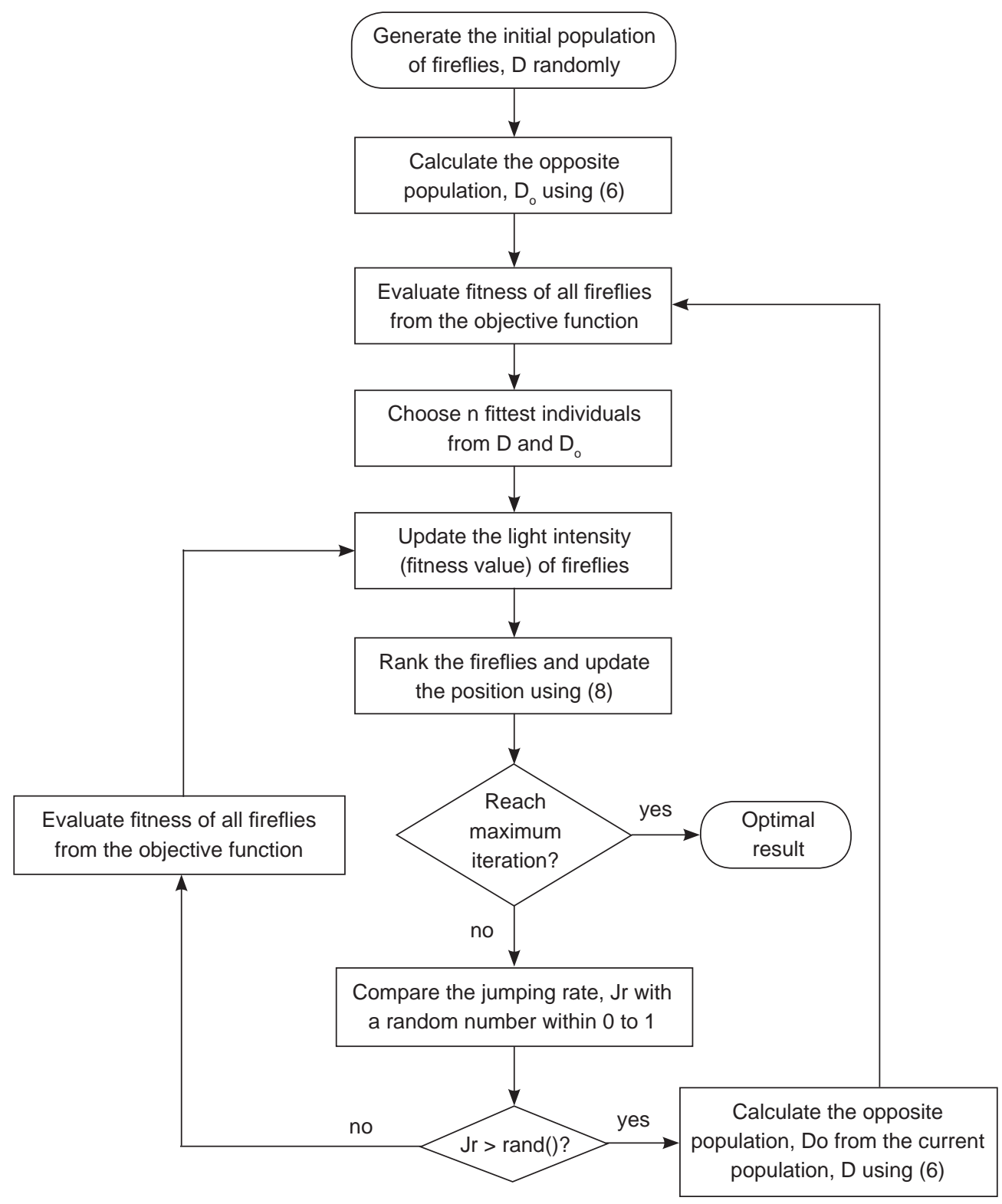

FIGURE 2. Flowchart for Enhanced Opposition Firefly Algorithm (EOFA)

After 50 runs on each test functions, the performances (fitness value) of each algorithm are reported in Table 2 and the summary of the performances is shown in Table 3 . It can be seen that the performances for FA are always the worst compared to GSA and EOFA. This can be caused by premature convergence after trapping in a local optimum. On the other hand, it can be observed that EOFA has the best performance for most of the test functions except for F2 and F11 where GSA outperforms EOFA. It is known from the reviews that, different algorithms may perform better than others for different problems (Elbeltagi et al. 2005 Rashedi et al. 2010). Performances in terms of convergence between FA, GSA and EOFA for randomly chosen functions are illustrated from Figure 3 to Figure 6. It can be seen from the figures that FA always converge pre-maturely and give an unsatisfied result. Meanwhile, both GSA and EOFA are able to escape from local minima and give better results. However, EOFA has the higher convergence rate and give better results if compared to GSA. 


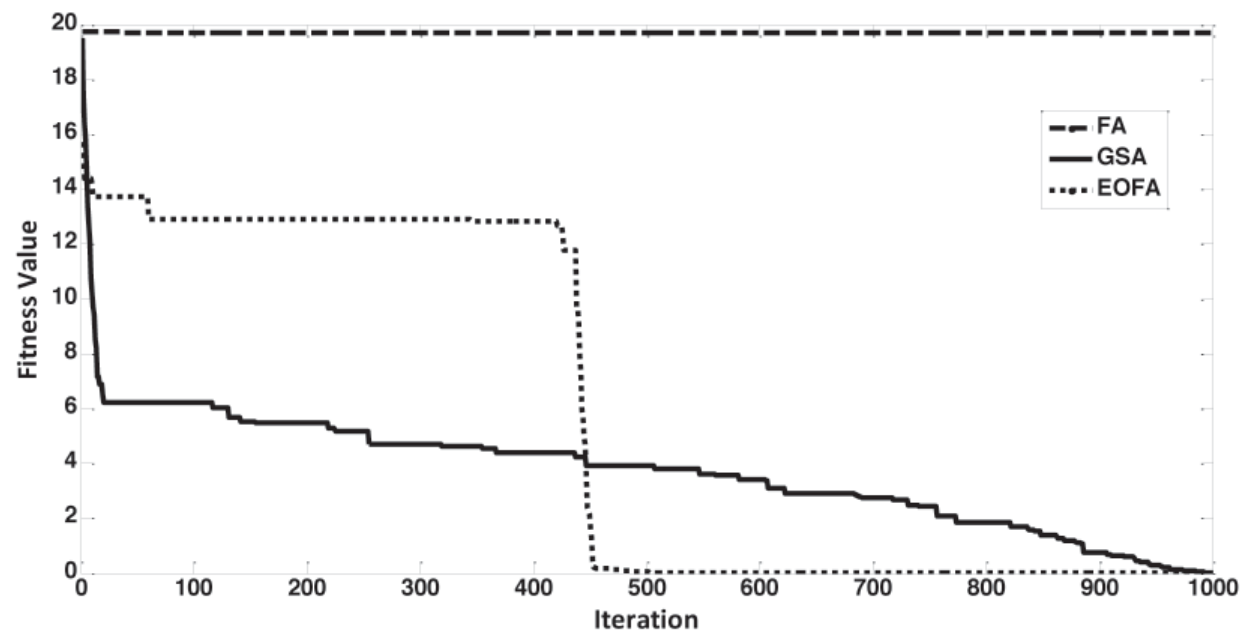

FIGURE 3. Comparison of performance of FA, GSA and EOFA for F1 with dimension size 30

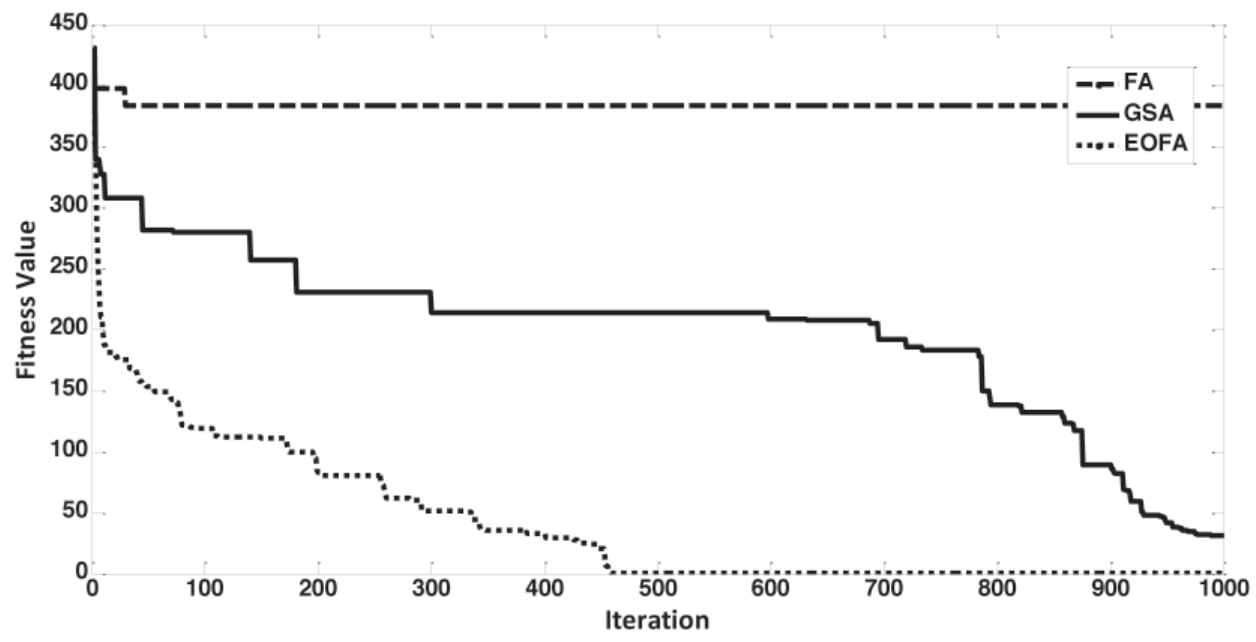

FIGURE 4. Comparison of performance of FA, GSA and EOFA for F10 with dimension size 30

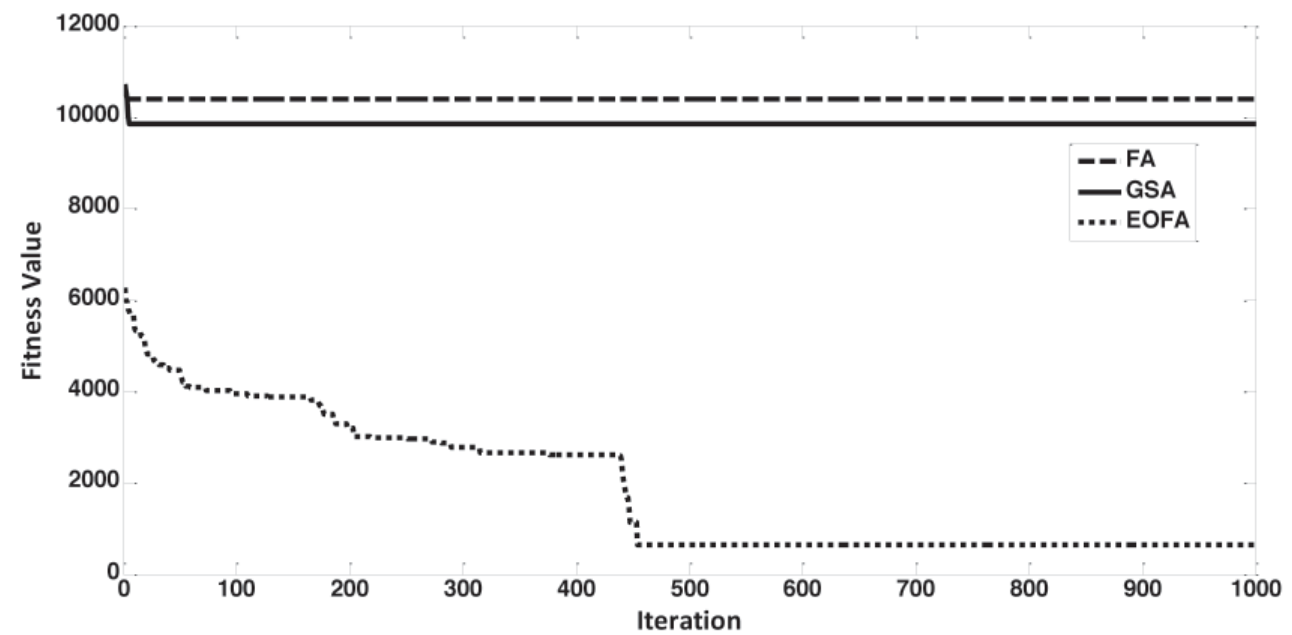

FIGURE 5. Comparison of performance of FA, GSA and EOFA for F12 with dimension size 30 


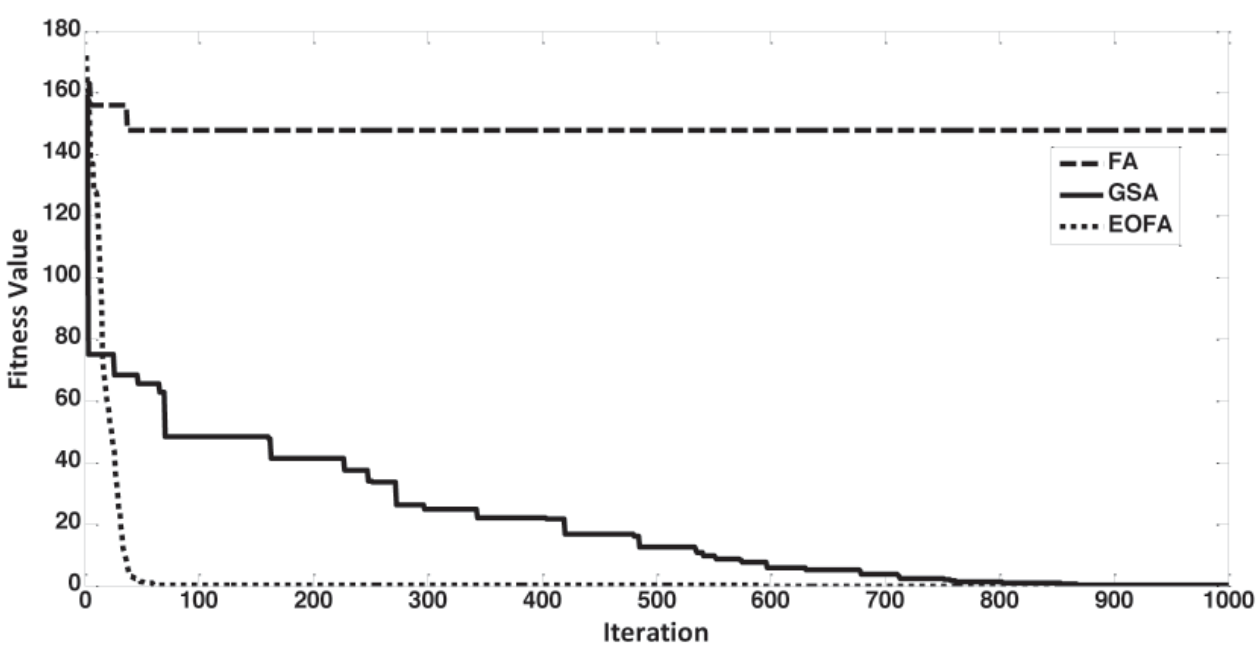

FIGURE 6. Comparison of performance of FA, GSA and EOFA for F13 with dimension size 30

TABLE 1. Test functions for unconstrained global optimization

\begin{tabular}{cccccccc}
\hline Function & $\begin{array}{c}\text { Name of } \\
\text { the function }\end{array}$ & $\begin{array}{c}\text { Dimension } \\
\text { size }\end{array}$ & $\begin{array}{c}\text { Global } \\
\text { minima }\end{array}$ & Function & $\begin{array}{c}\text { Name of } \\
\text { the function }\end{array}$ & $\begin{array}{c}\text { Dimension } \\
\text { size }\end{array}$ & $\begin{array}{c}\text { Global } \\
\text { minima }\end{array}$ \\
\hline F1 & Ackley Function & 30 & 0 & F9 & Powell Function & 30 & 0 \\
F2 & Beale Function & 2 & 0 & F10 & Rastrigin Function & 30 & 0 \\
F3 & Bohachevsky Function 1 & 2 & 0 & F11 & Rosenbrock Function & 30 & 0 \\
F4 & Bohachevsky Function 3 & 2 & 0 & F12 & Schwefel Function & 30 & 0 \\
F5 & Griewank Function & 30 & 0 & F13 & Sphere Function & 30 & 0 \\
F6 & Matya Function & 2 & 0 & F14 & Sum Square Function & 30 & 0 \\
F7 & Michalewicz Function & 10 & -9.66 & F15 & Zakharov Function & 30 & 0 \\
F8 & Perm Function & 30 & 0 & & & & \\
\hline
\end{tabular}

TABLE 2. Comparison of performances for GSA, FA and EOFA

\begin{tabular}{cccccccccc}
\hline $\begin{array}{c}\text { Optimization } \\
\text { algorithm }\end{array}$ & \multicolumn{3}{c}{ GSA } & \multicolumn{3}{c}{ FA } & \multicolumn{3}{c}{ Optimized Fitness Value } \\
Function & Best & Average & Worst & Best & Average & Worst & Best & Average & Worst \\
\hline F1 & 0.0096 & 0.015 & 0.024 & 18.52 & 19.60 & 19.97 & $8.88 \mathrm{E}-16$ & $3.8 \mathrm{E}-15$ & $7.99 \mathrm{E}-15$ \\
F2 & $2.07 \mathrm{E}-07$ & $6.09 \mathrm{E}-06$ & $6.84 \mathrm{E}-05$ & $3.60 \mathrm{E}-06$ & 0.069 & 0.91 & $5.46 \mathrm{E}-06$ & $3.99 \mathrm{E}-04$ & 0.0014 \\
F3 & $1.09 \mathrm{E}-06$ & $2.06 \mathrm{E}-05$ & $1.05 \mathrm{E}-04$ & 0.00021 & 0.55 & 3.35 & 0 & $4.88 \mathrm{E}-17$ & $2.22 \mathrm{E}-16$ \\
F4 & $1.87 \mathrm{E}-07$ & $9.87 \mathrm{E}-06$ & $3.98 \mathrm{E}-05$ & $6.11 \mathrm{E}-05$ & 0.30 & 2.08 & 0 & $1.78 \mathrm{E}-17$ & $5.55 \mathrm{E}-17$ \\
F5 & $6.98 \mathrm{E}-06$ & 0.0014 & 0.030 & 446.74 & 592.46 & 686.12 & 0 & $2.26 \mathrm{E}-16$ & $2.78 \mathrm{E}-15$ \\
F6 & $4.73 \mathrm{E}-09$ & $1.35 \mathrm{E}-07$ & $9.11 \mathrm{E}-07$ & $1.30 \mathrm{E}-05$ & 0.043 & 0.58 & $1.59 \mathrm{E}-40$ & $1.45 \mathrm{E}-36$ & $8.06 \mathrm{E}-36$ \\
F7 & -9.46 & -8.81 & -7.73 & -6.34 & -4.11 & -2.55 & -9.33 & -8.90 & -7.85 \\
F8 & $1.41 \mathrm{E}+82$ & $1.62 \mathrm{E}+85$ & $8.89 \mathrm{E}+85$ & $4.22 \mathrm{E}+81$ & $2.24 \mathrm{E}+84$ & $2.52 \mathrm{E}+85$ & $5.15 \mathrm{E}+77$ & $7.42 \mathrm{E}+80$ & $1.19 \mathrm{E}+82$ \\
F9 & 0.0014 & 0.0052 & 0.012 & 3658.18 & 5851.00 & 9794.40 & $9.69 \mathrm{E}-35$ & $6.14 \mathrm{E}-32$ & $7.94 \mathrm{E}-31$ \\
F10 & 15.99 & 34.50 & 53.79 & 353.45 & 394.46 & 429.40 & 0 & 0.99 & 3.19 \\
F11 & 25.75 & 27.53 & 29.47 & 710546.20 & 1211549 & 1629028 & 28.00 & 28.73 & 28.94 \\
F12 & 8389.22 & 9719.90 & 10278.85 & 8981.36 & 10257.49 & 11111.71 & 656.6 & 1094.737 & 1624.44 \\
F13 & $1.80 \mathrm{E}-4$ & $3.26 \mathrm{E}-4$ & $6.04 \mathrm{E}-4$ & 111.90 & 139.60 & 156.75 & $2.31 \mathrm{E}-35$ & $1.06 \mathrm{E}-32$ & $5.13 \mathrm{E}-32$ \\
F14 & 0.0019 & 0.0048 & 0.011 & 6228.04 & 8787.32 & 10279.92 & $3.52 \mathrm{E}-34$ & $1.46 \mathrm{E}-31$ & $6.56 \mathrm{E}-31$ \\
F15 & 24.16 & 51.79 & 73.96 & 708.22 & $5.47 \mathrm{E}+08$ & $3.92 \mathrm{E}+09$ & $5.84 \mathrm{E}-35$ & $1.92 \mathrm{E}-30$ & $1.60 \mathrm{E}-29$ \\
\hline
\end{tabular}


TABLE 3. Summary of the comparison of performances for GSA, FA and EOFA

\begin{tabular}{|c|c|c|c|c|c|}
\hline Function & $\begin{array}{l}\text { Optimization } \\
\text { algorithm with } \\
\text { best performance }\end{array}$ & $\begin{array}{c}\text { Optimization } \\
\text { algorithm with } \\
\text { worst performance }\end{array}$ & Function & $\begin{array}{c}\text { Optimization } \\
\text { algorithm with } \\
\text { best performance }\end{array}$ & $\begin{array}{c}\text { Optimization } \\
\text { algorithm with } \\
\text { worst performance }\end{array}$ \\
\hline $\mathrm{F} 1$ & EOFA & FA & F9 & EOFA & FA \\
\hline F2 & GSA & FA & F10 & EOFA & FA \\
\hline F3 & EOFA & FA & F11 & GSA & FA \\
\hline F4 & EOFA & FA & F12 & EOFA & FA \\
\hline F5 & EOFA & FA & F13 & EOFA & FA \\
\hline F6 & EOFA & FA & F14 & EOFA & FA \\
\hline F7 & EOFA & FA & F15 & EOFA & FA \\
\hline F8 & EOFA & FA & & & \\
\hline
\end{tabular}

CONCLUSION

This study has presented a new method known as EOFA to enhance the performance of standard FA. It was mainly based on the combination of opposition learning theory and the inertia weight function. The performance and effectiveness of EOFA was extensively tested on 15 unconstrained global optimization functions and the results were compared with other existing method, namely FA and GSA. According to their performances, it can be concluded that EOFA has higher effectiveness among the aforementioned optimization technique in obtaining the global optimum value for the test functions.

\section{REFERENCES}

Dorigo, M., Maniezzo, V. \& Colorni, A. 1996. Ant System: Optimization by a Colony of Cooperating Agents. Systems, Man, and Cybernetics, Part B: Cybernetics, IEEE Transactions on 26(1): 29-41.

Elbeltagi, E., Hegazy, T. \& Grierson, D. 2005. Comparison among five evolutionary-based optimization algorithms. Advanced Engineering Informatics 19(1): 43-53.

Goldberg, D. \& Holland, J. 1988. Genetic Algorithms and Machine Learning. Machine Learning 3(2-3): 95-99.

Hassanzadeh, T. \& Meybodi, M. R. 2012. A New Hybrid Algorithm Based on Firefly Algorithm and Cellular Learning Automata. Electrical Engineering (ICEE), 2012 20th Iranian Conference on: 628-633.

Hedar, A. 2013. Test Functions for Unconstrained Global Optimization.

Kennedy, J. \& Eberhart, R. 1995. Particle Swarm Optimization. IEEE International Conference on Neural Networks: 1942-1948.

Malisia, A. R. \& Tizhoosh, H. R. 2007. Applying OppositionBased Ideas to the Ant Colony System. Swarm Intelligence Symposium, 2007. SIS 2007. IEEE: 182189.
Rahnamayan, S., Tizhoosh, H. R. \& Salama, M. M. A. 2006 Opposition-Based Differential Evolution Algorithms. Evolutionary Computation, 2006. CEC 2006. IEEE Congress on: 2010-2017.

Rashedi, E., Nezamabadi-Pour, H. \& Saryazdi, S. 2009. GSA A gravitational search algorithm. Information Sciences 179(13): 2232-2248.

Rashedi, E., Nezamabadi-Pour, H. \& Saryazdi, S. 2010. BGSA: Binary gravitational search algorithm. Natural Computing 9(3): 727-745.

Shaw, B., Mukherjee, V. \& Ghoshal, S. P. 2012. A novel opposition-based gravitational search algorithm for combined economic and emission dispatch problems of power systems. International Journal of Electrical Power \& Energy Systems 35(1): 21-33.

Tizhoosh, H. R. 2005. Opposition-Based Learning: A New Scheme for Machine Intelligence. International Conference on Computational Intelligence for Modelling, Control and Automation: 695-701.

Yafei, T., Weiming, G. \& Shi, Y. 2012. An Improved Inertia Weight Firefly Optimization Algorithm and Application. 2012 International Conference on Control Engineering and Communication Technology (ICCECT): 64-68.

Yang, X.-S. 2009. Firefly Algorithms for Multimodal Optimization. Dlm. Stochastic Algorithms: Foundations and Applications, 5792, disunting oleh Watanabe, O. \& Zeugmann, T., 169-178. Berlin: Springer Berlin Heidelberg.

Yang, X.-S. 2010. Firefly Algorithm, Lévy Flights and Global Optimization. Dlm. Research and Development in Intelligent Systems XXVI, disunting oleh Bramer, M., Ellis, R. \& Petridis, M., 209-218. London: Springer London.

Yang, X. 2008. Nature-Inspired Metaheuristic Algorithms. Luniver Press. 
Ling Ai Wong*, Hussain Shareef, Azah Mohamed \& Ahmad Asrul Ibrahim

Department of Electrical, Electronic and System Engineering

Universiti Kebangsaan Malaysia

43600 UKM Bangi, Selangor D.E.

Malaysia

Phone: +603-8921 6590

*Corresponding author; email address: ling_ai89@hotmail.

com

Received date: $21^{\text {st }}$ July 2014

Accepted date: $8^{\text {th }}$ December 2014 